\title{
Bioactive components derived from bovine milk
}

\author{
Katarina Lisak Jakopović, Irena Barukčić*, Rajka Božanić
}

\begin{abstract}
University of Zagreb, Faculty of Food Technology and Biotechnology, Department of Food Engineering, Laboratory for Technology of Milk and Milk Products, Pierottijeva 6, 10000 Zagreb, Croatia

*Corresponding author: Phone:+38514605039; E-mail: ibarukcic@pbf.hr
\end{abstract}

\section{Abstract}

In recent years, functional foods and bioactive components in foods have drawn a lot of attention as well as interest of food scientists, nutritionists, health professionals, and consumers. The advent of this new food category has been facilitated by increasing scientific knowledge about the metabolic and genomic effects of diet and specific dietary components on human health. The relationship between health and diet is well known and it is a main key for prevention of variety of diseases. Milk is considered as a very good source of bioactive components and it has been known to contain macro- as well as micronutrients of high nutritional and therapeutic value. Also, bioactive components have been exploited from milk and dairy products for application in functional foods and for potential pharmaceutical use. Biologically active compounds guard neonates and adults against pathogens and illnesses. Some major bioactive components of milk are derived from caseins, whey proteins, lipids, lactoferrine, vitamins, immunoglobulins and growth factors. The aim of this paper was to provide an overview and explain the health effects of already known and recently detected bioactive components derived from bovine milk on humans.

\section{Key words: bioactive components, milk, bioactive peptides, bioactive lipids}

\section{Introduction}

Milk and milk products presents a good source of nutritional components like valuable proteins, lipids, lactose as well as micro- and macronutrients. It is well known that milk presents the nature's most complete food for growth and development of mammals. In recent years, there has been an increasing interest of consumers in functional food, which not only meets the primary function, but also has some benefits on human health. Functional food has emerged as a new approach to improve human nutrition and health in the environment where lifestyle diseases and aging populations are considered as a threat to the well-being of the so- ciety. Accordingly, the dairy industry has achieved a leading role in the development of functional foods and has already commercialized products that boost, for example, the immune system; reduce elevated blood pressure; combat gastrointestinal infections; help to control body weight; and prevent osteoporosis (Pihlanto, 2011). In addition to naturally present components (proteins, lipids, lactose and micro- and macronutrients) in milk, there are variety of other components that occur during milk processing or intestinal digestion (enzyme hydrolysis) and are called bioactive components since they provide various health benefits (Nongonierma and FitzGerald, 2015). The term bioactive components refers to compounds either 
naturally existing in food or the ones formed and/ or formulated during food processing that may have physiological and biochemical functions when consumed by humans. Food scientists have been exploiting bioactive components of milk and dairy products for application in functional foods and for potential pharmaceutical use. Milk is often considered as a functional food since it contains varieties of different bioactive components. Some bioactive components in milk are primary present in milk like growth factors (epidermal growth factor, neuronal growth factors, vascular endothelial growth factors, erythropoietin, growth regulating factors) and immune-related factors (immune cells, cytokines, chemokines) (Giacometti and Buretić-TomIjanović, 2017; Ballard and Morrow, 2013). Figure 1 presents an overview of bioactive components derived from milk.

\begin{tabular}{|c|c|c|}
\hline Lactoze and & Lipids & Lactoferin \\
\hline & \multirow{4}{*}{$\begin{array}{l}\text { BIOACTIVE } \\
\text { COMPONENTS } \\
\text { FROM MILK }\end{array}$} & Enzymes \\
\hline Growth factors & & \\
\hline and cytokines & & Peptides derived \\
\hline Immunoglobulins & & whey proteins \\
\hline
\end{tabular}

FIGURE 1. Schematic review of major bioactive components in milk

The most abundant and the most researched bioactive components are related to milk proteins (casein and whey proteins) and arise during their digestion or production of dairy products. Those are called bioactive peptides and refer to small fragments obtained from the maternal protein. They have biological function and are regarded as highly prominent ingredients for health promoting, functional foods or pharmaceutical preparations. Apart from the conventional knowledge, recent research is being carried out to investigate the "hidden" properties of milk, respectively the component that is present in milk and also possess a biological function in human organism, miRNA (microRNA) (Rani et al., 2017). The increasing number of studies that have been published over the past few years concerning bioactive components in foods, mostly in milk and dairy products, suggest that there is an increasing interest in their identification and application in both, food and industry. Thus, the main purpose of the present review paper was to give an overview of currently known bioactive components from milk, either naturally present or obtained after digestion and/or after milk processing. Also, a review of some most recently detected bioactive components has been given.

\section{Bioactive peptides}

Bioactive peptides can be derived from milk proteins, either casein or whey proteins. Production of bioactive peptides offers ingredients for a low-cost production and positive nutritional image associated to fermented milk. Generally, bioactive peptides can be produced by three main ways: by enzymatic hydrolysis with digestive enzymes; by fermentation of milk with proteolytic starter cultures; and by proteolysis with enzymes derived from microorganisms or plants. Also, some studies suggest the combination of these three mentioned models to be effective in generating functional bioactive peptides (Egger et al., 2017; Mann et al., 2019). Other animal or plant proteins are also a source of bioactive peptides, but milk proteins are the most important and the most abundant source, especially regarding the fact that milk is cost effective and is consumed on everyday basis. Bioactive peptides act as signalling molecules and thus play an important role in numerous physiological functions and pathogeneses (biological mechanism that leads to diseased state). When bioactive peptide is formed from maternal protein, one of the possible ways to act is being a regulatory compound with hormone-like activity (Mann et al., 2019). Some of physiological effects on human functions that bioactive peptides possess are effect on immune, cardiovascular, nervous and gastrointestinal system (Figure 2).

Having a role in human health by action on human functions, bioactive peptides have multiply beneficial effects like hypocholesterolemic, antioxidative, antithrombotic, antimicrobial, immunomodulatory, mineral binding, antihypertensive, antimicrobial and opioid antagonist/agonist (Biadala and Konieczny, 2018; Park and Nam, 2015). Bioactive peptides usually contain 3-20 amino acids residues per molecule. The activity of bioactive peptides has been related to the specific amino acid composition and sequence. Bioactive 
Antihypertensive Antioxidative

Antithrombotic Hypocholesterolemic

Cardiovascular system
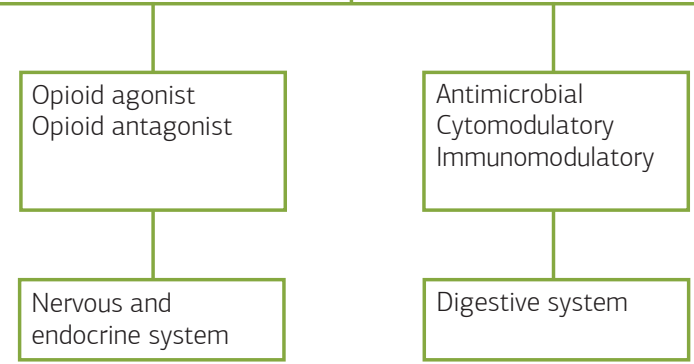

Antimicrobial Mineral binding

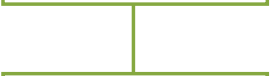

Immune system

FIGURE 2. Physiological effect of bioactive peptides formed from milk proteins on human functions (modified according to Mohanty et al., 2016)

peptides that possess the same activity usually have similar structural properties. Table 1 presents the main activities of bioactive peptides and their specific structural properties. In particular, the block of N-terminal group or/and of C-terminal group, as well as the phosphorylation of amino acids serine, threonine and tyrosine, prevent the peptide hydrolysis by digestive proteases and thus, give them a better opportunity to improve penetration of biological barriers. In general, bioavailability of bioactive peptides in human body depends on proteases present in gastrointestinal tract, elimination by renal function and ability to cross the cell membrane. Modification of the $\mathrm{N}$ - and $\mathrm{C}$-amino acid terminals protect the peptides from aminopeptidase and carboxypeptidase (Gianfranceschi et al., 2018; Mohanti et al., 2016).

Many bioactive peptides derived from milk can excrete two or more bioactive functions and thus may beneficially influence human health. Table 2 provides a review of the most researched and abundant bioactive peptides.

TABLE 1. The main bioactive peptides, their activities and structural properties (modified according to Pihlanto, 2011)

\begin{tabular}{l|l}
\hline Activity & Structural characteristics \\
\hline Opioid & $\begin{array}{l}\text { Tyrosine at N-terminus, connected with another aromatic residue (Phe or Tyr), } \\
\text { in the } 3^{\text {rd }} \text { or } 4^{\text {th }} \text { position }\end{array}$ \\
\hline $\begin{array}{l}\text { ACE inhibitory } \\
\text { (Antihypertensive) }\end{array}$ & Hydrophobic amino acids or positive charge of Lys or Arg on the C-terminus \\
\hline Antithrombotic & $\begin{array}{l}\text { Ile }{ }^{108}, \text { Lys } \\
\text { K-casein) }\end{array}$ \\
\hline Antioxidant & High amounts ${ }^{115}$ residues of casoplatelins (peptides derived from \\
\hline Hypocholesterolemic & $\begin{array}{l}\text { Low ratios of Met-Gly and Lys-Arg in proteins. High amount of hydrophobic } \\
\text { amino acids }\end{array}$ \\
\hline Antimicrobial & Positively charged residues and hydrophobic region that contains Trp \\
\hline
\end{tabular}


TABLE 2. Some bioactive peptide sequences and their functions released from caseins and whey proteins (modified according to Egger and Ménard, 2017)

\begin{tabular}{|c|c|c|c|}
\hline Sequence & Name & Fragment & Effect \\
\hline VPP/IPP & Lactotripeptides & $\beta$ - and k-casein & ACE inhibitor \\
\hline FFVAP & $a_{s 1}-$ Casokinin-5 & $\begin{array}{l}a_{s 1} \text {-casein } \\
f(23-27)\end{array}$ & $\begin{array}{l}\text { Antihypertensive } \\
\text { ACE inhibitor }\end{array}$ \\
\hline AVPYPQR & $\beta$-Casokinin-7 & $\begin{array}{l}\beta \text {-casein } \\
f(177-183)\end{array}$ & ACE inhibitor \\
\hline WLAHK & Lactokinin & $\begin{array}{l}\text { a-lactalbumin } \\
\text { f(104-108) }\end{array}$ & ACE inhibitor \\
\hline IPA & Lactokinin & $\begin{array}{l}\beta \text {-lactoglobulin } \\
f(78-80)\end{array}$ & ACE inhibitor \\
\hline TTMPLW & $\mathrm{a}_{\mathrm{s1}}$-Immunocasokinin & $\begin{array}{l}a_{51}-\text { casein } \\
f(194-199)\end{array}$ & $\begin{array}{l}\text { Immunomodulatory } \\
\text { Antihypertensive }\end{array}$ \\
\hline YPFPGPI & B-Casomorphin-7 & $\begin{array}{l}\beta \text {-casein } \\
f(60-66)\end{array}$ & $\begin{array}{l}\text { Opioid } \\
\text { Immunomodulatory }\end{array}$ \\
\hline IIAEK & Lactostatin & $\begin{array}{l}\beta \text {-lactoglobulin } \\
f(71-75)\end{array}$ & Hypocholesterolemic \\
\hline $\begin{array}{l}\text { FKCRRWQ } \\
\text { WRMKKLG } \\
\text { APSITCVRR } \\
\text { AF }\end{array}$ & Lactoferricin & $\begin{array}{l}\text { Lactoferin } \\
\mathrm{f}(17-41)\end{array}$ & $\begin{array}{l}\text { Antimicrobial } \\
\text { Immunomodulatory }\end{array}$ \\
\hline
\end{tabular}

Recently, a group of scientists (Nielsen et al., 2017) realized that over the past decade there has been an increasing number of identified bioactive peptides with their proven biological functions derived milk proteins. They formed a unique database (http://mbpdb.nws.oregonstate.edu) comprising the currently available literature and database is regularly updated (last time updated, May 2018). They identified 258 original research articles that describe the biological activity of certain peptide. The database consists of 944 bioactive peptides originated from ten different species (76\% from cow milk). Peptides included in database involve 177 peptides that manifest antimicrobial properties and 323 peptides with ACE-inhibitory activity. Rest of the peptides show antioxidant, opioid, anti-cancer, anti-inflammatory and immunomodulatory properties. The formed database allows identification of similar peptides with a high potential for function and guide further therapeutic discovery (Nielsen et al., 2017).

\section{Influence of bioactive peptides on human health}

Heart diseases and high blood pressure are a worldwide health problem, and there is a lack of effective pharmaceutical medicaments. Bioactive peptides may be one of the crucial ingredients that could be added to different food systems and by that significantly contribute to reduction of a global problem. Products fortified with bioactive peptides are already present on the market. Some products with health claim to reduce blood pressure can be found on the market under brand names Calpis (Sour milk enriched with VPP, IPP; Calpis C., Japan) and Evolus (Fermented milk drink, bioactive peptides: VPP, IPP; Valio Oy, Finland). In addition, product labelled with health claim that reduces stress is as well present on the market under the brand name Prodiet F200 (Flavoured milk drink, bioactive peptide: YLGYLEQLLR; ingredia, France) (Pihlanto, 2011).

Bioactive peptides are continuously being identified from either casein or whey protein hydrolysates. One of the novel bioactive peptide that has been identified is angiotensin I-converting enzyme (ACE)-inhibitory (ACEI) peptide, with amino acid sequence NMAINPSKENLCSTFCK. This peptide has been derived by tryptic hydrolysis from the $\mathrm{a}_{\mathrm{s2}}$-casein originating in fragment residues from the $25^{\text {th }}$ to the $41^{\text {st }}$ amino acid, and was subsequently identified by the UPLC-ESI-Q-TOF-MS/MS method. The $\mathrm{IC}_{50}$ (half maximal inhibitory concentration) value of the peptide was determined by a HPLC method, and amounted for $129.07 \mu \mathrm{M}$. Tu et al. (2018) ap- 
plied in their research a Lineweaver-Burk plot and showed that this peptide acted as a mixed-type inhibitor against ACE, which might be attributed to the peptide being susceptible to degradation by ACE, indicating that the mixed-type inhibition could partly be a result of the newly generated peptide fragments. Also, they evaluated physicochemical characteristics and the secondary structure by circular dichroism analysis and online prediction software (Expasy, PepDraw, and ProtParam) to identify the basic characteristics of this peptide. Moreover, a molecular docking was simulated by Discovery Studio 2017 R2 software to provide potential mechanisms underlying the ACEI activity of the peptides (Tu et al., 2018).

About $50 \%$ of milk solids pass into whey during the cheese or casein production, among which are the whey proteins (20\% of total protein), most of the lactose, minerals, and water soluble vitamins. Whey presents a rich and heterogeneous mixture of secreted proteins with wide-ranging chemical, physical and functional properties (Lisak Jakopović et al., 2016). Proteins lagged in whey include a-lactalbumin (a-La), $\beta$-lactoglobulin ( $\beta$-Lg), lactoferrin (Lf), lactoperoxidase, immunoglobulins, glycomacropeptide (GMP), proteose peptone, and a various growth factors (Lisak Jakopović et al., 2019; Lisak et al., 2013). These proteins have been involved in numerous biological functions, and show anticancer activity as well as influence to digestive functions. Whey proteins present an essential source of amino acids, but they have also been recognized and classified as dietary proteins which exert many other functions in vivo by means of biologically active peptides (Mann et al., 2019). Milk fermentation using lactic acid bacteria (LAB) or their proteinases has been described as a strategy to release ACE-inhibitory peptides from milk proteins by many authors (Hayes et al., 2006; Mann et al., 2018). The most often researched bioactive peptides that excrete ACE-inhibitory properties are Val-Pro-Pro (VPP) and Ile-Pro-Pro (IPP). Those peptides can be derived from casein by fermentation with Lactobacillus helveticus and Saccharomyces cerevisiae, respectively, and are found in the commercial sour milk product Calpis (Calpis, Co. Ltd., Tokyo). The antihypertensive effect of Calpis was shown by Yamamoto et al. (1994) and Hata et al. (1996). Results showed that Calpis decrease a systolic blood pressure for $17.7 \mathrm{mmHg}$ by consumption of $5 \mathrm{~mL} / \mathrm{kg}$ body weight of Calpis sour milk drink over an 8-hour period in spontaneously hypertensive rats (Yamamoto et al., 1994). Likewise, a significant reduction in blood pressure was observed in mildly hypertensive patients who took orally $95 \mathrm{~mL}$ of Calpis over an 8-week period (Hata et al., 1996). Particularly, it has been shown that non-hydrolysed $\beta$-Lg has a very low ACE-inhibitory activity but its hydrolysis (using pepsin, trypsin, chymotrypsin, and/or other proteases) resulted in high levels of ACE inhibition (73\% - $90 \%$ ). Pan et al. (2012) identify a novel angiotensin I-converting enzyme (ACE) inhibitory peptide from whey protein hydrolysed by trypsin. The amino acid sequence of the peptide with the greatest ACE inhibitory characteristics was Leu-Leu (LL).

The increased production of reactive oxygen species (ROS) and reactive nitrogen species, combined with overtaking endogenous antioxidant defence mechanisms so called oxidative stress is a significant factor for the initiation or progression of lifestyle related diseases. Consumption of antioxidants appears to benefit endogenous antioxidant defence strategies in the fight against oxidative stress (Fang et al., 2002). Studies have shown that peptides with antioxidant properties can be released from milk proteins (Pihlanto, 2006). The use of synthetic antioxidants, such as butylated hydroxytoluene, butylated hydroxyanisole, propyl gallate, and tert-butylhydroquinone, has been restricted because of their potential toxic effects on humans. On the other hand, bioactive peptides are considered natural antioxidants and have attracted a great deal of interest because of their safety and availability from a wide range of protein sources (Brandelli et al., 2015). Contributing to the antioxidant properties is also attributable to amino acids with aromatic residues that can donate protons to electron-deficient radicals. This property improves the radical-scavenging properties of the amino acid residues.

Diabetes is a serious chronic disease that occurs either when the pancreas does not produce enough insulin (a hormone that regulates blood sugar, or glucose), or when the body cannot effectively use the insulin it produces. Diabetes is one of the four no communicable diseases targeted for action by global researchers. Over the years, the 
prevalence of diabetes has been progressively increasing. According to the International Diabetes Federation (IDF, 2017), 425 million adults were living with diabetes in 2017, compared to 250 million in 2007. The global prevalence (age-standardized) of diabetes has nearly doubled in 10 years. Diabetes complications can lead to heart attack, stroke, blindness, kidney failure, and lower limb amputation (Korhonen, 2009). Consumption of milk protein-derived bioactive peptides has been linked with serum glucose regulatory properties in humans. Different mechanisms may include an insulinotropic activity, in cretin secretory actions, as well as the influence on activities of different metabolic enzymes involved in the regulation of serum glucose such as dipeptidyl peptidase IV (DPP-IV), a-amylase, and a-glucosidase (Parodi, 2016; Lacroix and Li-Chan, 2014).

Furthermore, milk is a rich source of antimicrobial proteins and peptides, capable of exerting antimicrobial activities comparable to antibiotics. This effect is due to the synergistic activity of naturally occurring peptides, immunmodulatory proteins such as lactoferrin, lactoperoxidase, and lysozyme, and is greater than any individual contribution (Clare et al., 2003). The most studied ones are the lactoferricins, derived from bovine and human Lf (Kitts and Weiler, 2003). Also, a few negatively charged peptides derived from $\beta$ - Lg (Pellegrini et al., 2001) and a-La showed antibacterial activity against Gram-positive bacteria and a weak activity against Gram-negative bacteria. The disruption of normal membrane permeability is at least partly responsible for the antibacterial mechanism of lactoferricins. The difference in net charge, charge distribution, size, amino acid sequence, and secondary structure along with amphipathicity might be responsible for the differential behaviour of the identified antibacterial peptides against bacteria (Brandelli et al., 2015).

Another property that bioactive peptides exert is opioid activity. Opioid peptides are those peptides that possess pharmacological similarities to opium, apropos pain relief. Opioid peptide sequences typically contain Tyr-Gly-Gly-Phe at their $\mathrm{N}$-terminal side, and in the case of atypical opioid peptides, a Tyr residue is found at the $\mathrm{N}$-terminus. These peptides have been reported to behave like morphine in the brain. These have been found with- in milk proteins, both in casein (as 1-, as2-, $\beta$-, and $\mathrm{k}-)$ (casomorphins) and whey proteins (lactorphins). However, the major opioid peptides are fragments of $\beta$-casein, called $\beta$-casomorphins (Clare and Swaisgood, 2000). All k-casein fragments, known as casoxins behave as opioid antagonists (Severin and Wenshui, 2005). Opioid peptides have also been found encrypted within the primary sequence of whey proteins such as Lf, $\beta$-Lg, and bovine serum albumin (Mann et al., 2019).

\section{Bioactive lipids}

Generally, lipids from milk fat possess a broad range of biological functions, and they have role in energy storage, intracellular signalling, thermogenesis, and structural integrity. Lipids also play an important role in pathology and prevention of numerous diseases like cardiovascular, neurological diseases, obesity, and metabolic syndrome, such as obesity and thus lipids have appeared as a component of nutraceutical products. Lipids as nutraceuticals are safe and have a potential therapeutic and health benefits, which may influence the outcome of many debilitating diseases (Kumar et al., 2018). Bovine milk fat is composed of more than 400 fatty acids with different chemical composition. Most of these fatty acids are esterified to the glycerol molecule backbone and appear in milk fat mostly as triacylglycerols (Jensen, 2002; Gantner et al., 2015). Conjugated linoleic acid (CLA) is a positional and geometrical isomer of cis - 9, cis - 12 - octadecadienoic acid (C18:2) with a conjugated double bond system. The major CLA isomer in milk fat is 9 - cis, 11 - trans, also called rumenic acid (Butler et al., 2009; Collomb et al., 2006). CLA is formed partially by bioconversion of polyunsaturated fatty acids in the rumen by anaerobic bacteria, e.g., Butyrovibrio fibrisolvens, and primarily endogenously by desaturation of vaccenic acid in the mammary gland of lactating cows (Griinari et al., 2000). Milk fat is the richest natural source of CLA with contents ranging from 2 to $53.7 \mathrm{mg} \mathrm{g}^{-1}$ fat that have been recorded in different studies (Collomb et al., 2006). The wide range of CLA values can be attributed to various factors such as the feeding regime, forage preservation, geographical regions, and breed of cows as well as goats and sheep. Also, 
some studies have demonstrated that pasture feeding can significantly increase CLA concentrations as compared to indoor feeding. The grass composition of pasture seems to affect the CLA level because it was found to be almost 2-3 times higher in the milk of cows grazed in the alpine region as compared to milk from cows grazed in the lowlands (Collomb et al., 2001). Experimental studies have demonstrated that feeding cows with meals containing plant oils and/or marine oils can effectively increase the CLA content. Also, it has been proven that concentrates rich in linoleic acid (rapeseed, soybean, sunflower) have a better impact than other polyunsaturated plant oils (peanut, linseed), whereas the dietary fish oils and their combination with plant oils appear even more effective than plant oils alone (Korhonen, 2009; Roy et al., 2006; Shingfield et al., 2006). Another biologically active lipid group in milk fat are the polar lipids, which are mainly located in the milk fat globule membrane (MFGM). Milk fat membrane globule is a highly complex biological structure that surrounds the fat globule stabilizing it in the continuous aqueous phase of milk and preventing it from enzymatic degradation by lipases (Mather, 2000; Spitsberg, 2005; Kamau et al., 2010). The membrane consists of about $60 \%$ proteins and $40 \%$ lipids that are mainly composed of triglycerides, cholesterol, phospholipids, and sphingolipids. The polar lipid content of raw milk ranges between 9.4 and $35.5 \mathrm{mg}$ per $100 \mathrm{~g}$ of milk. The major phospholipid fractions are phosphatidylethanolamine and phosphatidylcholine followed by smaller amounts of phosphatidylserine and phosphatidylinositol. The major sphingolipid fraction is sphingomyelin with smaller portions of ceramides and gangliosides. During milk processing into different dairy products, the polar lipids are preferentially enriched in the aqueous phases like skimmed milk, buttermilk and butter serum (Kumar et al., 2018). There are lot of researches that examine influence of MFGM on human health. Group of authors Li et al. (2018) showed that MFGM improved the gut microbiota dysbiosis induced by high-fat diet in mice. Also, they indicated that there was a correlation between gut microbiota and obesity-related indexes. MFGM also alleviated high-fat diet-induced intestinal inflammation by decreasing the levels of interleukin-6 (IL-6), tumor necrosis factor-a (TNF-a), toll-like receptor 4 (TLR4) and in- creasing the expression of tight junction proteins including zonulin-1 (ZO-1) and occludin. Moreover, MFGM significantly decreased the levels of lipopolysaccharides (LPS), IL-6 and TNF-a in serum of high-fat diet-induced mice. Findings from Li et al. (2018) demonstrated that MFGM supplementation ameliorated obesity-related inflammation and endotoxemia partly via modulating the composition of gut microbiota in mice challenged with a highfat diet. Furthermore, Castro-Gomez et al. (2016) evaluated antiproliferative effectiveness of lipid extracts and their neutral and polar fractions on nine human cancer cell lines. They concluded that these fractions, rich in phospho- and sphingolipids, were strongly antiproliferative against human ovary and colon cancer cells (Castro-Gomez et al., 2016). The richest source of milk fat membrane globule is buttermilk, which is unfortunately neglected. However, buttermilk should be aimed at promoting its use of polar lipid fractions as functional food additives.

\section{Growth factors}

The presence of growth factors, either promoting or growth or inhibitory activity for different cell types was first demonstrated in human colostrum and milk (Pouliot and Gauthier, 2006). Until now, growth factors that have been identified in milk are the beta cellulin (BTC), the epidermal growth factor (EGF), the fibroblast growth factor 1 and 2 (FGF1 and FGF2), the insulin like growth factor I and II (IGF-I and IGF-II), the transforming growth factor $\beta 1$ and $\beta 2$ (TGF- $\beta 1$ and TGF- $\beta 2$ ) and the platelet - derived growth factor (PDGF). Available literature quotes that concentrations of the mentioned growth factors in bovine milk were the highest in colostrum during the first hours after calving and afterwards decrease substantially. The most abundant growth factors in bovine milk are the EGF in a concentration from 2 to $155 \mathrm{ng} \mathrm{mL}^{-1}$ followed by the IGF-I in a concentration from 2 to101 $\mathrm{ng} \mathrm{mL}^{-1}$ and the IGF-II in a concentration from 2 to 107 ng $\mathrm{mL}^{-1}$. Further growth factors that are also abundant in bovine milk are the TGF- $\beta 2$ in a concentration from 13 to $71 \mathrm{ng} \mathrm{mL}^{-1}$, whereas the concentrations of the other known growth factors remain below 4 ng $\mathrm{mL}^{-1}$ (Pouliot and Gauthier, 2006). Gener- 
ally, the growth factors are polypeptides and their molecular masses range between 6 to $30 \mathrm{kDa}$ with amino acid residues varying from 53 (EFG) to about 425 (TGF- $\beta 2$ ), respectively. Some authors who have been researching influence of growth factors on thermal treatment concluded that growth factors are relatively well resistant to pasteurization and even to UHT (ultrahigh temperature) heat treatment (Gauthier et al., 2006). The main biological functions of the milk growth factors have been reviewed by Gauthier et al. (2006) as well as by Tripathi and Vashishtha (2006). EGF and BTC stimulate the proliferation of epidermal, epithelial, and embryonic cells. They also inhibit the secretion of gastric acid and promote wound healing and bone resorption. Growth factors from the TGF- $\beta$ family play an important role in the development of the embryo, tissue repair, formation of bone and cartilage, and regulation of the immune system. In addition, both forms of TGF- $\beta$ are known to stimulate the proliferation of connective tissue cells and inhibit proliferation of lymphocytes and epithelial cells. Also, both forms of IGF stimulate proliferation of many cell types and regulate some metabolic functions, e.g., glucose uptake and synthesis of glycogen (Pouliot and Gauthier, 2006).

\section{Novel bioactive component from milk}

It is well known that human milk is the best, complete and only food that is necessary for normal growth and development of infants until six months of their life. There is a question that can be asked, how is it possible that since today is not produced infant formula that can substitute human milk with all of its biological functions? This question implies for itself that there are some gaps in detailed knowledge about the understanding and as well knowing the exact composition of milk. Recently, group of scientists (Rani et al., 2017) established the presence of bioactive component from milk, miRNA (microRNA). The presence of miRNAs has been established in almost every biological fluid. miRNAs are a class of small non-coding RNAs which are involved in regulation of gene expres- sion. miRNAs approximately have 22 nucleotides in length and they were discovered for the first time in Caenorhabditis elegans (Lee et al., 1993). miRNAs are involved in different processes like development, proliferation, immunity, apoptosis and much more (Bushati and Cohen, 2007). By applying bioinformatics methods it has been predicted that miRNAs most probably regulates $30 \%$ of the protein coding genes in mammals. Milk as well as other biological fluids contains miRNAs, which are called the "Milk miRNAs". Milk miRNAs have been isolated from different fractions from milk like lipid fraction, exosomal fractions or from whey fraction (Rani et al., 2017). For isolation of miRNA different methods have been used like the Trizol LS extraction, the miRNeasy kit, the mir-Vana miRNA isolation kit and the quantitative RT-PCR, which are the most frequently, used ones (Lekchnov et al., 2016). miRNA shows a specific stability when present in milk, and its main and most important property is the resistance to unfavourable environmental conditions such as boiling, low pH, freezing or thawing up. The reason for such stability in the extreme environmental conditions is most probably the protective role of a lipid bilayer that is covering miRNAs (Baddela et al., 2016). Since miRNAs is resistant to low $\mathrm{pH}$, it can easily pass through the gastrointestinal tract without degradation and thus it can affect the processes in the body. Expression of milk miRNA is variable during different stages of lactation. Colostrum contains higher amounts of miRNA than milk. Besides having a biological function, quantities of miRNA can be used for detection of milk adulteration. Group of scientists (Chen et al., 2010) identified 245 miRNAs in milk and they selected seven of those (miR-26a, miR-26b, miR-200c, miR-21, miR-30d, miR-99a, and miR148a) which are stable across the whole lactation. If milk is adulterated by dilution, levels of miRNAs drop significantly compared to the raw milk and thus, miRNAs presents a potential and the most precise biomarker in the dairy industry for detection of adulterated milk. miRNAs have been involved in an immune related processes by regulation of the immune cells like development, homeostasis, proliferation, differentiation, migration, communication and others. miRNAs are post-transcriptional regulators that can control 
almost all the aspects of the immune cell behaviour. Since 245 miRNAs are identified from milk, their biological functions have not been investigated yet. Some miRNAs are well researched like the miR-27b that has a positive effect on immunosuppressive activity by inhibition of T-cell proliferation. In addition, miR-27b can modulate the immune responses and thus presents an oxidative stress responsive miRNA. Furthermore, miR-106b inhibit by targeting autophagy related genes and consequently combats against intracellular bacterial infections. miR-24 significantly represses phagocytotic processes and associated inflammatory cytokines in cells. Most of miRNAs are involved in immune-stimulating processes (Rani et al., 2017) and thus play an important role in the human health.

\section{Future perspective}

Bioactive components, especially those derived from milk, belong to the most researched field over the past decade. Dairy industry has a leading role in creating the products that possess beneficial impacts to human health. ACE inhibitory properties of casein or whey proteins hydrolysates have been proven in vivo and in vitro and are commercially available via various functional dairy products such as fermented milks or cheese. Future perspective in this area might be achieved by the use of predictive models and technological developments in largescale continuous production and isolation of bioactive peptides. In addition, there is a lack of research focused on studying interactions between bioactive components and other food components during processing, so there is a great need to explore those. Generally, milk- and milk products- derived bioactive components are safe for human use and they can be regarded as highly valuable ingredients for inclusion in a healthy lifestyle owing to their ability to prevent or reduce diseases such as stress, cardiovascular diseases, obesity and others. Bioactive milk components possess a high potential for enhancing various biological functions in the human body resulting in a positive impact on the human health, and might replace conventional pharmaceutical therapy in future. Thus, by consuming food with declared bioactive components the consumers not only take food but are also taking care for health and at the same time, with the terminal outcome of preventing or even curing some diseases.

\section{Bioaktivni sastojci kravljeg mlijeka}

\section{Sažetak}

Funkcionalna hrana i bioaktivni sastojci hrane posljednjih su godina privukli veliku pažnju i zanimanje znanstvenika, nutricionista, zdravstvenih djelatnika te samih potrošača. Samo saznanje o funkcionalnoj hrani uvelike je olakšano napretkom znanosti te spoznajama o metaboličkim i genomskim utjecajem na prehranu te utjecajem određenih sastojaka hrane na ljudsko zdravlje. Poveznica zdravlja i prehrane je dobro poznata i glavni je ključ za prevenciju mnogih bolesti. Mlijeko se smatra izuzetno dobrim izvorom bioaktivnih sastojaka, a odavno je poznato da je namirnica s dobrim sastavom makro- i mikronutrijenata. Osim što se bioaktivni sastojci mlijeka prirodno nalaze u mlijeku i mliječnim proizvodima, oni se iz istih izoliraju te se koriste kao bioaktivni sastojci za proizvodnju funkcionalne hrane ili pak u farmaceutskoj industriji. Bioaktivni sastojci mlijeka imaju zaštitnu ulogu, kod novorođenčadi i odraslih, protiv patogena i bolesti. Glavni bioaktivni funkcionalni sastojci mlijeka nastaju iz kazeina, proteina sirutke, mliječne masti, laktoferina, vitamina, imunoglobulina i faktora rasta. Stoga je cilj rada bio dati pregled poznatih i onih tek nedavno detektiranih bioaktivnih sastojaka mlijeka te njihov utjecaj na zdravlje čovjeka.

\section{Ključne riječi: bioaktivni sastojci, mlijeko, bioaktivni peptidi, bioaktivni lipidi}


1. Baddela, V.S., Nayan, V., Rani, P., Onteru, S. K., Singh, D. (2016): Physicochemical Biomolecular Insights into buffalo milkderived nanovesicles. Applied Biochemistry and Biotechnology 178, 544-557. https://doi.org/10.1007/s12010-015-1893-7

2. Ballard, O., Morrow, A.L. (2013): Human milk composition: nutrients and bioactive factors. Paediatrics Clinics of North America 60, 49-74., https://doi.org/10.1016/j.pcl.2012.10.002

3. Biadala, A., Konieczny, P. (2018): Goat's milk derived bioactive components - a review. Mljekarstvo 68 (4), 239-251. https://doi.org/10.15567/mljekarstvo.2018.0401

4. Brandelli, A., Daroit, D.J., Folmer Corrêa, A.P. (2015): Whey as a source of peptides with remarkable biological activities. Food Research International 73, 149-161. https://doi.org/10.1016/j.foodres.2015.01.016

5. Bushati, N., Cohen, S.M. (2007): microRNA functions. Annual Review of Cell and Developmental Biology 23, 175-205. https://doi.org/10.1146/annurev.cellbio.23.090506.123406

6. Butler, G., Collomb, M., Rehberger, B., Sanderson, R., Eyrea, M., Leiferta, C. (2009): Conjugated linoleic acid isomer concentrations in milk from high- and low-input management dairy systems. Journal of the Science of Food and Agriculture 89, 697-705 https://doi.org/10.1002/jsfa.3504

7. Castro-Gómez, P., Rodríguez-Alcalá, L.M., Monteiro, K.M., Ruiz, A.L.T.G., Carvalho, J.E., Fontecha, J. (2016): Antiproliferative activity of buttermilk lipid fractions isolated using food grade and non-food grade solvents on human cancer cell lines. Food Chemistry 212, 695-702. https://doi.org/10.1016/j.foodchem.2016.06.030.

8. Chen, X., Gao, C., Li, H., Huang, L., Sun, Q., Dong, Y., Guan, D., Hu, X., Zhao, S., Li, L., Zhu, L., Yan, Q., Zhang, J., Zen, K., Zhang, C.Y. (2010): Identification and characterization of microRNAs in raw milk during different periods of lactation, commercial fluid, and powdered milk products. Cell Research 20, 1128-1137. https://doi.org/10.1038/cr.2010.80

9. Clare, D.A., Catignani, G.L., Swaisgood, H.E. (2003): Biodefense properties of milk: the role of antimicrobial proteins and peptides. Current Pharmaceutical Design 9, 1239-1255.

10. Clare, D.A., Swaisgood, H.E. (2000): Bioactive milk peptides: A prospectus. Journal of Dairy Science 83, 1187-1195. https://doi.org/10.3168/jds.S0022-0302(00)74983-6

11. Collomb, M., Bütikofer, U., Sieber, R., Bosset, J.O., Jeangros, B. (2001): Conjugated linoleic acid and trans fatty acid composition of cow's milk fat produced in lowlands and highlands. Journal of Dairy Research 68, 519-523.

12. Collomb, M., Schmid, A., Sieber, R., Wechsler, D., Ryhänen, E.L. (2006): Conjugated linoleic acids in milk fat: Variation and physiological effects. International Dairy Journal 16, 13471361., https://doi.org/10.1016/j.idairyj.2006.06.021

13. Egger, L., Ménard, O. (2017): Update on bioactive peptides after milk and cheese digestion. Current Opinion in Food Science 14, 116-121. http://dx.doi.org/10.1016/j.cofs.2017.03.003

14. Egger, L., Ménard, O., Baumann, C., Duerr, D., Schlegel, P., Stoll, P., Vergères, G., Dupont, D., Portmann, R. (2017): Digestion of milk proteins: Comparing static and dynamic in vitro digestion systems with in vivo data. Food Research International, In Press. https://doi.org/10.1016/j.foodres.2017.12.049
15. Fang, Y.Z., Yang, S., Wu, G. (2002): Free radicals, antioxidants and nutrition. Nutrition 18, 872-879. https://doi.org/10.1016/S0899-9007(02)00916-4

16. Gantner, V., Mijić, P., Baban, M., Škrtić, Z., Turalija, A. (2015): The overall and fat composition of milk of various species. Mljekarstvo 65 (4), 223-231. https://doi.org/10.15567/mljekarstvo.2015.0401

17. Gauthier, S.F., Pouliot, Y., and Maubois, J.L. (2006): Growth factors from bovine milk and colostrum: composition, extraction and biological activities. Lait 86, 99-125 https://dio.org/10.1051/lait:2005048

18. Giacometti, J., Buretić-Tomljanović, A. (2017): Peptidomics as a tool for characterizing bioactive milk peptides. Food Chemistry 230, 91-98. https://doi.org/10.1016/j.foodchem.2017.03.016

19. Gianfranceschi, G.L., Gianfranceschi, G., Quassinti, L., Bramucci, M. (2018): Biochemical requirements of bioactive peptides for nutraceutical efficacy. Journal of Functional Foods 47, 252-263. https://doi.org/10.1016/j.jf.2018.05.034.

20. Griinari, J.M., Corl, B.A., Lacy, S.H., Choinard, P.Y. , Nurmela, K.V., Bauman, D.E. (2000): Conjugated linoleic acid is synthesized endogenously in lactating dairy cows by $\delta 9$ - desaturase. Journal of Nutrition 130, 2285-2291. https://doi.org/10.1093/jn/130.9.2285

21. Hata, Y., Yamamoto, M., Ohni, H., Nakajima, K., Nakamura, Y., Takano, T. (1996): A placebo - controlled study of the effect of sour milk on blood pressure in hypertensive subjects. American Journal of Clinical Nutrition 64, 767-771. https://doi.org/10.1093/ajcn/64.5.767

22. Hayes, M., Coakley, M., O'Sullivan, L., Stanton, C., Hill, C., Fitzgerald, G.F., Murphy, J.J., Ross, R.P. (2006): Cheese as a delivery vehicle for probiotics and biogenic substances. Australian Journal of Dairy Technology 61, 132-141.

23. International Diabetes Federation (2017) IDF Diabetes Atlas, eight edition 2017. http://diabetesatlas.org/

24. Jensen, R.G. (2002): The composition of bovine milk lipids: January 1995 to December 2000. Journal of Dairy Science 85, 295-350. https://doi.org/10.3168/jds.S0022-0302(02)74079-4

25. Kamau, S.M., Cheison, S.C., Chen, W., Liu, X.M., Lu, R.R. (2010): Alpha-lactalbumin: its production technologies and bioactive peptides. Comprehensive Reviews in Food Science and Food Safety 9, 197-212. https://doi.org/10.1111/j.1541-4337.2009.00100.x

26. Kitts, D.D., Weiler, K. (2003): Bioactive proteins and peptides from food sources. Applications of bioprocesses used in isolation and recovery. Current Pharmaceutical Design 9, 13091323. https://doi.org/10.2174/1381612033454883

27. Korhonen, J.H. (2009): Bioactive Components in Bovine Milk. In: Bioactive Components in Milk and Dairy Products, Park, Y.W., Wiley-Blackwell, 15-42. https://doi.org/10.1002/9780813821504

28. Kumar, S., Sharma, B., Bhadwal, P., Sharma, P., Agnihotri, N. (2018): Lipids as Nutraceuticals: A Shift in Paradigm, In Handbook of Food Bioengineering, Therapeutic Foods, Holban, A.M., Grumezescu, A.M., Academic Press, 51-98. https://doi.org/10.1016/B978-0-12-811517-6.00003-9. 
29. Lacroix, I.M.E., Li-Chan, E.C.Y. (2014): Overview of food products and dietary constituents with antidiabetic properties and their putative mechanisms of action: A natural approach to complement pharmacotherapy in the management of diabetes. Molecular Nutrition and Food Research 58, 61-78. https://doi.org/10.1002/mnfr.201300223

30. Lee, R.C., Feinbaum, R. L., Ambros, V. (1993): The C. elegans heterochronic gene lin-4 encodes small RNAs with antisense complementarity to lin-14. Cell 75, 843-854.

31. Lekchnov, A.E., Zaporozhchenko, I.A., Morozkin, E.S., Bryzgunova, O.E., Vlassov, V.V., Laktionov, P.P. (2016): Protocol for miRNA isolation from biofluids. Analytical Biochemistry 499, 78-84. https://doi.org/10.1016/j.ab.2016.01.025

32. Li, T., Gao, J., Du, M., Mao, X. (2018): Milk fat globule membrane supplementation modulates the gut microbiota and attenuates metabolic endotoxemia in high-fat diet-fed mice. Journal of Functional Foods 47, 56-65. https://doi.org/10.1016/j.jf.2018.05.038.

33. Lisak Jakopović, K., Barukčić, l., Božanić, R. (2016): Physiological significance, structure and isolation of a-lactalbumin. Mljekarstvo 66 (1), 3-11. https://doi.org/10.15567/mljekarstvo.2016.0101

34. Lisak Jakopović, K., Cheison, S.C., Kulozik, U., Božanić, R. (2019): Comparison of selective hydrolysis of a-lactalbumin by acid Protease $\mathrm{A}$ and Protease $\mathrm{M}$ as alternative to pepsin: potential for $\beta$-lactoglobulin purification in whey proteins. Journal of Dairy Research 86 (1), 114-119. https://doi.org/10.1017/S0022029919000086

35. Lisak, K., Toro-Sierra, J., Božanić, R., Kulozik, U., Cheison, S.C. (2013): Chymotrypsin selectively digests $\beta$-lactoglobulin in whey protein isolate away from enzyme optimal conditions: Potential for native a-lactalbumin purification, Journal of Dairy Research 80 (1), 14-24. https://doi.org/10.1017/S0022029912000416

36. Mann, B., Athira, S., Sharma, R., Kumar, S., Sarkar, P. (2019): Bioactive Peptides from Whey Proteins, In: Whey Proteins, Deeth, C.H., Bansal, N., Academic Press, 519-547. https://doi.org/10.1016/B978-0-12-812124-5.00015-1.

37. Mather, I.H. (2000): A review and proposed nomenclature for major proteins of the milk-fat globule membrane. Journal of Dairy Science 83, 203-247. https://doi.org/10.3168/jds.S0022-0302(00)74870-3

38. Mohanty, D.P., Mohapatra, S., Misra, S., Sahu, P.S. (2016): Milk derived bioactive peptides and their impact on human health A review. Saudi Journal of Biological Sciences 23, 577-583. http://dx.doi.org/10.1016/j.sjbs.2015.06.005

39. Nielsen, S.D., Beverly, R.L., Qu, Y., Dallas, D.C. (2017): Milk bioactive peptide database: A comprehensive database of milk protein-derived bioactive peptides and novel visualization. Food Chemistry 232, 673-682. http://dx.doi.org/10.1016/j.foodchem.2017.04.056

40. Nongonierma, A.B., FitzGerald, R.J. (2015): Bioactive properties of milk proteins in humans: A review. Peptides 73, 20-34. https://doi.org/10.1016/j.peptides.2015.08.009

41. Pan, D., Cao, J., Guo, H., Zhao, B. (2012): Studies on purification and the molecular mechanism of a novel ACE inhibitory peptide from whey protein hydrolysate. Food Chemistry 130 , 121-126. https://doi.org/10.1016/j.foodchem.2011.07.011
42. Park, Y.W., Nam, M.S. (2015): Bioactive peptides in milk and dairy products: A review. Korean Journal for Food Science and Animal Resources 35(6), 831-840. https://10.5851/kosfa.2015.35.6.831

43. Parodi, P.W. (2016): Cooperative action of bioactive components in milk fat with PPARs may explain its antidiabetogenic properties. Medical Hypotheses 89, 1-7. https://doi.org/10.1016/j.mehy.2015.12.028

44. Pellegrini, A., Dettling, C., Thomas, U., Hunziker, P. (2001): Isolation and characterization of four bactericidal domains in the bovine $\beta$-lactoglobulin. Biochimica et Biophysica Acta 1526 (2), 131-140. https://doi.org/10.1016/s0304-4165(01)00116-7

45. Pihlanto, A. (2006): Antioxidative peptides derived from milk proteins. International Dairy Journal 16, 1306-1314. https://doi.org/10.1016/j.idairyj.2006.06.005

46. Pihlanto, A. (2011): Bioactive Peptides. In: Milk Proteins Products, Fuquay, J.W Encyclopaedia of Dairy Science, $2^{\text {nd }}$ ed. Academic Press, 879-886. https://doi.org/10.1016/B978-0-12-374407-4.00351-4

47. Pouliot, Y., Gauthier, S.F. (2006): Milk growth factors as health products: Some technological aspects. International Dairy Journal 16, 1415-1420. https://doi.org/10.1016/j.idairyj.2006.06.006

48. Rani, P., Yenuganti, V.R., Shandilya, S., Onteru, S.K., Singh, D. (2017): miRNAs: The hidden bioactive component of milk. Trends in Food Science \& Technology 65, 94-102. https://doi.org/10.1016/j.tifs.2017.05.007

49. Roy, A., Ferlay, A., Shingfield, K.J., Chilliard, Y. (2006): Examination of the ersistency of milk fatty acid composition responses to plant oils in cows given different basal diets, with particular emphasis on trans-C18:1 fatty acids and isomers of conjugated linoleic acid. Animal Science 82, 479-492. https://doi.org/10.1079/ASC200658

50. Séverin, S., Wenshui, X. (2005): Milk biologically active components as nutraceuticals: review. Critical Review of Food Science and Nutrition 45 (7-8), 645-656. https://doi.org/10.1080/10408690490911756

51. Shingfield, K. J., Reynolds, C. K., Herva's, G., Griinari, J. M., Grandison, A. S., Beever, D.E. (2006): Examination of the persistency of milk fatty acid composition responses to fish oil and sunflower oil in the diet of dairy cows. Journal of Dairy Science 89, 714-732. https://doi.org/10.3168/jds.S0022-0302(06)72134-8

52. Spitsberg, V.L. (2005): Bovine milk fat globule membrane as a potential nutraceutical. Journal of Dairy Science 88, 2289-2294. https://doi.org/10.3168/jds.S0022-0302(05)72906-4

53. Tripathi, V., Vashishtha, B. (2006): Bioactive compounds of colostrum and its application. Food Reviews International 22(3), 225-244. https://doi.org/10.1080/87559120600694606

54. Tu, M., Wang, C., Chen, C., Zhang, R., Liu, H., Lu, W., Jiang, L., Du, M. (2018): Identification of a novel ACE-inhibitory peptide from casein and evaluation of the inhibitory mechanisms. Food Chemistry 256, 98-104. https://doi.org/10.1016/j.foodchem.2018.02.107.

55. Yamamoto, N., Akino, A., and Takano, T. (1994): Antihypertensive effect of different kinds of fermented milk in spontaneously hypertensive rats. Bioscience, Biotechnology and Biochemistry 58, 776-778. 